\title{
MOTIVACIONE STRATEGIJE REŠAVANJA AGENCIJSKOG PROBLEMA
}

\author{
Jelena Lukić
}

Ekonomski fakultet, Univerzitet u Beogradu, Beograd, Srbija

\begin{abstract}
Apstrakt:
Cilj ovog rada je da predstavi motivacionu putanju rešavanja agencijskog problema. Pored materijalnih strategija kompenzacija koje čine osnovna plata, beneficije, privilegije, pogodnosti, različiti bonusi, akcije, opcije na akcije, potrebno je primenjivati i razne vidove nematerijalnih strategija motivacije kojima će se zadovoljiti potrebe zaposlenih višeg reda kao što su: potrebe za priznanjem, postignućem, ličnim razvojem. U radu je prikazan okvir sa aktivnostima kojih bi menadžeri trebalo da se pridržavaju prilikom formulisanja i implementacije efektivne motivacione strategije za prevazilaženje agencijskog problema.
\end{abstract}

\section{Ključne reči:}

korporativno upravljanje, agencijski problem, kompenzacione strategije, nematerijalne strategije motivacije.

\section{UVOD}

Efektivni sistem korporativnog upravljanja olakšava proces donošenja odluka i delegiranje ovlašćenja i odgovornosti u okviru organizacije. Najveći problem koji se javlja zbog razdvajanja upravljanja od vlasništva proističe iz činjenice da se interesi menadžera i vlasnika ne podudaraju u potpunosti i da sami vlasnici nemaju neograničene mogućnosti kontrole rada menadžera koji upravljaju njihovim kapitalom. Sa druge strane, menadžeri raspolažu znatno kvalitetnijim i sveobuhvatnijim informacijama koje im daju mogućnosti za devijantno ponašanje usled čega nastaje problem na relaciji principal (menadžer) - agent (vlasnik), koji je u literaturi poznatiji kao agencijski problem. Vremenom su se izdvojile dve putanje za rešavanje agencijskog problema: kontrolna putanja koja obuhvata odbore direktora, internu i eksternu reviziju i monitoring aktivnosti menadžera i; motivaciona putanja koja podrazumeva definisanje kompenzacionih šema kao ključnih mehanizama za motivaciju menadžera da donose odluke u skladu sa interesima vlasnika [3]. Cilj ovog rada je da ukaže da motivaciona putanja rešavanja agencijskog problema pored materijalnih strategija motivacije treba da obuhvata i nematerijalne strategije motivacije. Značaj teme proizilazi iz činjenice da budući uspeh svake organizacije određuje humani kapital [4], koji se sastoji iz znanja, iskustva, posvećenosti i motivacije [1], koji je potrebno usmeriti i motivisati tako da se pored egzistencijalnih potreba zadovolje i potrebe zaposlenih višeg reda gde na scenu stupaju nematerijalne strategije motivacije.

\section{RAZVOJ EFEKTIVNE MOTIVACIONE STRATEGIJE}

Neadekvatno formulisane i implementirane strategije motivacije uzrokuju brojne probleme u organizacijama. Neki od simptoma koji ukazuju da motivacione strategije nisu usklađene sa poslovnom strategijom su:

1) kompanija ima poteškoće da privuče i zadrži talente i lidere,

2) kompenzacione šeme ne odražavaju poslovnu strategiju,

3) menadžeri i zaposleni nisu motivisani i ne postižu željene performanse,

4) vlasnici i menadžeri nisu svesni postojanja strategije kompenzacija u kompaniji,

5) kompenzacione šeme ne odražavaju kulturu date kompanije [4].
Svi ovi simptomi ukazuju da je potrebno preispitati postojeću strategiju motivacije. Iako svaka kompanija ima svoj individualni pristup formulisanju i implementaciji motivacione strategije, koji odgovara njenoj misiji i viziji, vremenom su identifikovane određene aktivnosti kojih bi se trebalo pridržavati kako bi strategija motivacije bila efektivna. Pre svega, neophodno je ispitati interni kontekst i sagledati poslovnu strategiju i efektivnost organizacije. Zatim je potrebno identifikovati kljlučne ciljeve vlasnika, resurse koji predstavljaju izvore konkurentske prednosti, potrebu za talentima i liderima. Pored internog, potrebno je sagledati i eksterno okruženje i prakse konkurenata $\mathrm{u}$ pogledu sistema nagrađivanja i merenja performansi. Nakon analize internog i eksternog okruženja i uspostavljanja osnovnih koncepata, kompanije pristupaju procesu definisanja ključnih ciljeva koji se žele postići strategijom kompenzacija. Takođe, u ovoj fazi se identifikuju faktori kao što su: uporediva grupa preduzeća u odnosu na koju će se vršiti poređenje kompenzacionih šema, merila performansi, usklađenost motivacione strategije sa ostvarenim performansama.

Proces formulisanja i primene materijalnih strategija kompenzacija podrazumeva određivanje osnovne plate, raznih beneficija, privilegija, pogodnosti, kratkoročnih podsticaja u vidu raznih bonusa i dugoročnih podsticaja u vidu akcija i opcija na akcije [3]. Kompenzacione šeme jesu neophodne, ali su vremenom postale nedovoljne za motivisanost menadžera i zaposlenih. Uočeno je da u velikom broju slučajeva one nemaju uticaja na stavove i nivo posvećenosti zaposlenih, već da samo privremeno utiču na ponašanje čime stvaraju privid da je problem motivacije rešen i da je cilj postignut. Kompenzacionim šemama menadžment nesvesno kreira okruženje u kojem se zaposleni osećaju kontrolisano, unapred znaju šta će dobiti ako urade određeni zadatak što često za krajnji efekat ima frustraciju zaposlenih. $\mathrm{Ne}$ treba izgubiti iz vida da kompenzacione šeme mogu nepovoljno uticati na uspostavljanje veza i odnosa sa ostalim zaposlenima jer oni počinju da gledaju jedni na druge kao na konkurente [6]. Činjenica da su se poslovne strategije promenile u odnosu na prošli period stavila je u fokus potrebu za inoviranjem, preduzimanjem rizika, intenzivnu saradnju sa ostalim kolegama, ali i partnerima izvan kompanije. Kompenzacione strategije usmeravaju zaposlene da ostvaruju kvantitativne rezultate (brojke i predviđene procente) usled čega oni ostaju učaureni u već ustaljenim rutinama i procesima, ne težeći da budu inovativni i da sarađuju sa drugima. Svetska ekonomska kriza je nametnula i brojna finansijska ograničenja kompanijama usled 
čega menadžeri stalno preispituju svoje troškove poslovanja. Jedan od najznačajnijih troškova je trošak za različite vidove kompenzacija zaposlenih. Kompanije koje ne ulože dodatni napor i zalaganje da uspostave i nematerijalne strategije motivacije, oslanjajući se isključivo na materijalne vidove motivacije slobodno možemo poistovetiti sa roditeljima kojima je jednostavno lakše da svoju ljubav prema deci iskažu novcem Kao rezultat neuvažavanja nematerijalnih strategija motivacije kompanije će se suočiti sa nedostatkom lojalnosti i posvećenosti zaposlenih [8].

Sa ciljem da podstaknemo menadžere da primenjuju i nematerijalne strategije motivacije, u nastavku rada ćemo prikazati okvir koji sadrži aktivnosti koje predstavljaju osnovu za formulisanje efektivne strategije motivacije. Prikazani okvir predstavlja nadgradnju okvira za uspostavljanje efektivne strategije kompenzacija koji su predstavili Ferakone i Kompan u svom radu iz 2004. godine [4]. Pored originalnih pet aktivnosti, okvir je proširen šestom aktivnošću koja obuhvata nematerijalne strategije motivacije o kojima će biti reći u nastavku rada. i skupocenim poklonima, umesto zagrljajima i pažnjom [5].

motivacija predstavlja osećaj i želju zaposlenih za postignućem, rezultatima i uključenosti i ne može se postići materijalnim vidovima nagrađivanja usled čega su napredni menadžeri iz oblasti ljudskih resursa počeli da osmišljavaju nematerijalne strategije motivacije. Pregledom literature moguće je izdvojiti sledeće nematerijalne strategije motivacije:

1) oblikovanje posla (rotacija, proširivanje, obogaćivanje);

2) opunomoćivanje zaposlenih;

3) participacija zaposlenih;

4) povratna informacija;

5) fleksibilni oblici radnog vremena;

6) oblikovanje kulture date organizacije.

Oblikovanje posla predstavlja proces putem kojeg se određuje sadržaj određenog posla sa ciljem da se izbegnu monotonija i dosada koje proističu iz visoke specijalizacije i podele posla, a da se istovremeno posao učini zanimljivijim i izazovnijim. Ključne strategije oblikovanja posla su rotacija, proširivanje i obogaćivanje posla. Periodična rotacija zaposlenih sa jednog specijalizovanog posla na drugi u skladu sa njihovim znanjima i sposobnostima sprečava dosadu i monotoniju zaposlenih, ali zahteva njihovu fleksibilnost. U slučaju proširivanja, posao se oblikuje sa ciljem da obuhvata dva ili više prethodno razdvojena srodna zadatka u jedan posao koji se dodeljuje jednom zaposlenom. Obogaćivanje posla podrazumeva pružanje ovlašćenja zaposlenima da odlučuju o načinu i metodama obavljanja svojih radnih zadataka, dodeljivanjem složenijih i izazovnijih zadataka. Zaposleni dobijaju celovit zadatak, stiču osećaj autonomije u njegovom izvršavanju, ulažu dodatnu energiju i napor kako bi se pokazali u što boljem svetlu, a istovremeno postižu svoje lično usavršavanje i razvoj.

Opunomoćivanje zaposlenih podrazumeva prenos zadataka i ovlašćenja, ali i prenos odgovornosti sa menadžera na zaposlene. Smatra se da se opunomoćivanjem [Izvor: Adaptacija autora na osnovu Ferracone, R., i Compaan, R. "Linking Executive Compensation Strategy to Business Strategy." u Executive Compensation, urednici M. Davis i J. Edge, San Diego: Windsor Professional Information, 2004, pp. 18-42.]

\section{NEMATERIJALNE STRATEGIJE MOTIVACIJE}

Nematerijalne strategije motivacije imaju za cilj zadovoljenje potreba zaposlenih višeg reda kojima svi oni koji su zaposleni u novoj ekonomiji teže. To su potreba za priznanjem, pripadanjem i ličnim razvojem. Generalno, iako su imali različite pristupe izvorima motivacije, autori (Maslow, Herzberg i Deci) su došli do zaključka da postoje dva ključna izvora motivacije: unutrašnji (intrinzični) i spoljašnji (ekstrinzični). Unutrašnja zaposlenih postiže njihova lojalnost, produktivnost i posvećenost obavljanju posla, jer oni postaju uključeni u brojna pitanja vezana za poslovanje i budući razvoj kompanije [10].

Participacija zaposlenih, kao strategija nematerijalne motivacije, ima za cilj: da poveća motivaciju, zainteresovanost zaposlenih, da omogući kompaniji da iskoristi znanja, veštine, kreativnost zaposlenih, poboljša kvalitet odluka, poveća identifikaciju zaposlenih sa organizacijom [2]. Sam program participacije podrazumeva učešće zaposlenih u definisanju ciljeva, donošenju odluka, rešavanju problema i uvođenju promena u organizaciju [10].
Neophodne pretpostavke

- Povratna informacija mora biti tačna i objektivna;

- Pravovremena, konkretna, usmerena na ponašanje, ne na osobu;

- Iskrena i verodostojna;

- Mora podsticati zaposlene na bolje rezultate.

\section{Efekti povratne informacije}

- Povećava motivaciju i podstiče samopouzdanje;

- Omogućava profesionalni razvoj;

- Pojašnjava očekivanja i standard uspešnosti;

- Vodi uspostavljanju otvorenih odnosa i međusobnog poverenja;

- Poučava kako treba raditi određeni posao;

- Daje signal da se rad prati i ceni.

Tabela 1: Pretpostavke i efekti povratne informacije o radu zaposlenih

[Izvor: Buntak, K., Drožđek, I. i Kovačić, R. "Nematerijalna motivacija u funkciji upravljanja ljudskim potencijalima.” Tehnički glasnik, vol. 7, no. 2, 2013, pp. 213-219.] 
Povratna informacija se smatra veoma značajnom strategijom nematerijalne motivacije. Međutim, da bi povratna informacija imala svoje efekte, moraju biti zadovoljene osnovne pretpostavke (tabela 1).

Fleksibilni oblici radnog vremena obuhvataju [9]:

- Skraćenu radnu nedelju u kojoj zaposleni nekim danima rade duže od 8 sati kako bi odradili obavezno nedeljno radno vreme za manji broj dana i time ostvarili pravo na jedan ili dva slobodna dana. Najčešče rade četiri dana nedeljno po 10 sati i stiču pravo na jedan ceo slobodan dan.

- Fleksibilno radno vreme sa određenim obaveznim prisustvom kada zaposleni imaju obavezu da budu prisutni u tačno definisano vreme (na primer od 12 do 15 časova), dok preostali deo radnih sati sami određuju. Takođe, brojne kompanije imaju klizno radno vreme - definisan interval za dolazak i odlazak na posao uz obaveznih 8 radnih sati.

- Deljeni posao kada dvoje ili više ljudi dele jedan posao koji nosi puno radno vreme. Ovaj vid fleksibilnog radnog vremena je posebno značajan za roditelje sa malom decom.

- Rad od kuće koji je postao moguć razvojem informaciono-komunikacionih tehnologija gde zaposleni sami određuju vreme u okviru kog će odraditi dodeljene zadatke.

Organizaciona kultura kao faktor motivacije zaposlenih mora biti uspostavljena tako da uvažava i poštuje zaposlene, njihovu kreativnost, veštine i znanje, ohrabruje i podstiče inovacije, permanentno učenje i usavršavanje zaposlenih, vrednuje na adekvatan način rezultate i zalaganje zaposlenih [7].

\section{ZAKLJUČAK}

Efikasnost korporativnog upravljanja se može poboljšati uspostavljanjem adekvatnog motivacionog sistema tako što će se interesi menadžera, koji upravljaju poverenim kapitalom, povezati sa interesima vlasnika. U ovom radu je prikazan okvir za uspostavljanje efektivne motivacione strategije kojom se može prevazići agencijski problem. Pored materijalnih strategija mo- tivacije, koje su u literaturi i praksi široko zastupljene, rad je ukazao na značaj, potrebu za definisanjem i implementaciju raznih vidova nematerijalnih strategija motivacije. Cilj rada je bio da ohrabri menadžere da pored raznih kompenzacionih šema primenjuju i nematerijalne strategije motivisanja kako bi se zadovoljile potrebe zaposlenih višeg reda, kao što su potreba za priznanjem, postignućem i ličnim razvojem.

\section{LITERATURA}

[1] Ballout, H. "Career success: the efects of human capital, person-environment fit and organizational support." Journal of Management Psychology, vol 22, no. 8, 2007, pp. 741765.

[2] Buntak, K., Drožđek, I. i Kovačić, R. "Nematerijalna motivacija u funkciji upravljanja ljudskim potencijalima.” Tehnički glasnik, vol. 7, no. 2, 2013, pp. 213-219.

[3] Đuričin, D., i Janošević, S. "Strategijska analiza ljudskih resursa.” Ekonomske teme, vol. 47, no. 1, 2009, pp. 1-47.

[4] Ferracone, R., i Compaan, R. "Linking Executive Compensation Strategy to Business Strategy." u Executive Compensation, urednici Davis M. i Edge J. San Diego: Windsor Professional Information, 2004, pp. 18-42.

[5] Kohn, A. Rethinking Rewards. Harvard Business School Publishing Corporation, 2001.

[6] Kohn, A. Why Incentive Plans Cannot Word. Harvard Business School Publishing Corporation, 2001.

[7] Mašić, B., i dr. Menadžment. Beograd: Univerzitet Singidunum, 2010.

[8] Pfeffer, J. "Six dangerous myths about pay." Harvard Business Review, 1998: May - June issue.

[9] Robbins, S., i Coulter, M. Management. New Jersey: Upper Saddle River, 2003.

[10] Vidaković, T. "Nematerijalne nagrade i njihov uticaj na motivaciju zaposlenih.” Časopis za ekonomiju i tržišne komunikacije, vol. 2, no. 1, 2012, pp. 161-177.

\section{MOTIVATIONAL STRATEGIES FOR THE AGENCY PROBLEM RESOLUTION}

Jelena Lukić

Faculty of economics, University of Belgrade, Kamenička 6, Belgrade, Serbia, jelena.jl.lukic@gmail.com

\begin{abstract}
:
The aim of this paper is to present motivational path for the agency problem resolution. Apart material compensational strategies which encompass basic salary, benefits, privileges, various bonuses, shares, options on shares, it is necessary to apply various types of non-monetary motivational strategies that will meet the needs of employees of a higher level, such as need for recognition, achievement, personal development. This paper presents a framework with activities which managers should adhere in process of formulation and implementation of effective motivational strategy for overcoming the agency problem.
\end{abstract}

\section{Key words:}

corporative governance, agency problem, compensation strategy, non-monetary strategies of motivation. 